\title{
Impacts Of The Aggregate Economic And Financial Conditions On Output In An Emerging Economy
}

Yu Hsing, Southeastern Louisiana University, USA Susan M. L. Zee, Southeastern Louisiana University, USA Michael C. Budden, Southeastern Louisiana University, USA Robert F. Cope III, Southeastern Louisiana University, USA

\begin{abstract}
This study formulates the theoretical model based on the money market equilibrium, the goods market equilibrium, and an augmented aggregate supply function. The sample ranges from 1996.Q1 to 2009.Q3 and has 55 observations. Applying the generalized autoregressive conditional heteroskedasticity (GARCH) model, this paper finds that Brazil's real GDP is positively impacted by real M2 money supply, the real stock price, world output and the expected inflation rate and is negatively influenced by the government deficit as a percent of GDP, the real $B R L / U S D$ exchange rate and the U.S. Treasury bill rate. The first and third quarters exhibit seasonal effects. Therefore, expansionary monetary policy is more effective than deficit-financed expansionary fiscal policy, and pursuing real appreciation, promoting a robust stock market, and maintaining a strong world economy will benefit the Brazilian economy.
\end{abstract}

Keywords: Monetary Policy; Fiscal Policy; Exchange Rate Depreciation or Appreciation; Stock Prices, World Output; World Interest Rate

\section{INTRODUCTION}

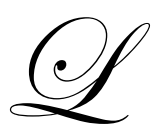

ike many other emerging countries, Brazil has suffered economic slowdowns because of the recent global financial crisis. Its real GDP measured in the 2000 constant price declined $9.23 \%$ from 268.969 million reias in 2008.Q3 to 244.149 million reais in 2009.Q1. Household consumption and business investment expenditures also decreased to varying degrees. Its balance of trade changed from a surplus of 2.838 billion reais in 2008.Q4 to a deficit of 6.271 billion reais in 2009.Q4. (International Financial Statistics, International Monetary Fund, April 2010). During the global financial crisis, the Brazilian Bovespa stock index closely followed the downward trend of stock prices in advanced countries and declined $59.96 \%$ from a high of 73,517 on May 20, 2008 to a low of 29,435 on October 27, 2008. After that, the index has continued to show an upward trend with volatility and rose $136.55 \%$ to 69,629 on November 24, 2010 (Bloomberg.com). The BRL/USD exchange rate depreciated $68.08 \%$ from 1.558 on August 1, 2008 to 2.6187 on December 5, 2008. Since then, the Brazilian real has shown a trend of appreciation, and the BRL/USD exchange rate reached 1.7209 on November 24, 2010 (Federal Reserve Bank of St. Louis; The Wall Street Journal). The stronger real suggests that Brazilian exports would decline and its imports would rise, contributing to potential trade deficits and relieving import-induced inflationary pressures.

This paper examines whether macroeconomic and financial variables would affect real output in Brazil. This paper has several focuses. First, a model is formulated based on an equilibrium in the goods market, an equilibrium in the money market, and an augmented aggregate supply function. Second, expansionary monetary and fiscal policies are represented by an increase in real money supply and a higher budget deficit as a percent of GDP, respectively. The exchange rate policy is represented by real depreciation or appreciation of the Brazilian real in order to stimulate net exports, reduce import-induced inflation, increase international capital inflows, and raise real output. Third, an advanced time series methodology such as the generalized autoregressive conditional 
heteroskedasticity $(\mathrm{GARCH})$ model (Bollersev, 1986) is applied in empirical work in order to test whether the error variance may be influenced by the past squared error and the past error variance.

\section{LITERATURE SURVEY}

There are several recent works studying Brazil's macroeconomic and financial conditions, strengths and weaknesses, and other related subjects. Barbosa-Filho (2008) and Cerisola and Gelos (2009) show that inflation targeting in Brazil has reduced inflation expectations and its dispersion, output growth and its volatility, and the real interest rate. Gomes and Paz (2005) find evidence of a J-curve and the Marshall-Lerner condition for Brazil whereas Hsing (2008) and Kalyoncu, et al. (2009) show lack of support for a J-curve for Brazil. Lyons (2010) indicates that to contain inflation and to attract foreign capital, a relatively high interest rate leads to the much-overvalued Brazilian real, which has hurt manufacturing and exports. Tabak (2003) finds that the random walk hypothesis for Brazil can be rejected before 1994 and can be confirmed after 1994. Worthington and Higgs (2003) and Guttler, Meurer, and Da Silva (2008) show lack of evidence of the market efficiency hypothesis for Brazil. Canarella and Pollard (2007) indicate that high volatility of the stock market in Brazil is either due to local or global crises but is temporary.

According to The Economist (September 12, 2009; October 15, 2009), the International Monetary Fund (2009), Rathbone (2010), Stewart, Lyons, and Wessel (2010), and Stewart and Jeffris (2010), and Adrogué, Cerisola and Gelos (2010), Brazil's major economic strengths lie in the positive impacts of macroeconomic stability, effective monetary and fiscal policies, a relatively low government debt/GDP ratio, a relatively low foreign debt, a sound financial system, inflation targeting, a relatively low cost of a stimulus package equal to $1 \%-1.5 \%$ of GDP, tax credit for certain consumer durable goods, increased bank credit availability to households and firms, robust domestic demand, a large auto market, a flexible exchange rate, and diversification of international trade and economic activities. Among major weaknesses are persistent decrease in public investment in infrastructure, a steady increase in government spending, a relatively high inflation rate, large current account deficits, a relatively high interest rate, and a strong currency hurting manufacturing and exports. A decrease in government consumption spending will reduce the real interest rate, increase investment spending, and enhance economic growth.

Ferrari-Filho and Spanakos (2009) review economic policies and compare economic performances between Brazil and China. According to their analysis, during 2000 - 2007, Brazil's average inflation rate of $7.0 \%$ was relatively high; the average nominal and real interest rates were around $17.5 \%$ and $9.8 \%$; respectively; and the average growth rate of real GDP was only $3.4 \%$. They argue that pursuing a flexible exchange rate and free international capital mobility may create too much exchange rate volatility and become destabilizing factors for some of the emerging countries. They show that a floating or flexible exchange rate system with high volatility and high capital mobility may not be as desirable as a pegged exchange rate system with very low volatility and partial capital mobility with many restrictions.

The International Monetary Fund (2010) makes a prediction of the Brazilian macroeconomic condition for 2010. Real GDP, domestic demand, private consumption, gross investment will grows at an annual rate of $7.1 \%$, $9.1 \%, 8.3 \%$, and $13.8 \%$, respectively. The overall budget balance as a percent of GDP will have a deficit of $1.6 \%$, and the public sector net debt as a percent of GDP will decline to $36.7 \%$ from $42.3 \%$ in 2009. The current account as a percent of GDP will have a deficit of $2.8 \%$. The inflation will rise 5.4\%. It seems that Brazil is expected to weather the global financial crisis well except that its inflation rate will be slightly higher than its target inflation rate of $4.5 \%$.

O'Grady (2010) analyzes the potential impact of the Fed's quantitative easing on Brazil's economy and Brazil's fiscal condition. Due to a future weaker U.S. dollar and a stronger real, net exports will decline, and protectionism and demand for subsidies will rise. Because of a strong real, arduous regulations, and high trade barriers, manufacturing will become less competitive. The cost of sterilization to prevent the real from appreciating would be very high. A rising household debt/income ratio from 18\% in 2005 to $35 \%$ in 2010 will cause domestic demand to decline. Due to a high tax burden of $35 \%$ of GDP and a large amount of populist transfer payment programs, the budget deficit will deteriorate. 


\section{THEORETICAL MODEL AND METHODOLOGY}

Extending Bernanake and Blinder (1988), Mankiw (1988), Gali (1992), Revier (2000), Romer (2006) and other related studies, the model specifies aggregate spending as a function of real GDP, government spending, government revenues, the real interest rate, the real stock price, the real exchange rate, and world output. The demand for money is determined by the interest rate, real output, the real stock price, the real exchange rate, and the world interest rate. In the augmented aggregate supply function, the inflation rate is affected by the expected inflation rate, the deviation of real output from potential output, and the real exchange rate. Suppose that the goods and money markets are in equilibrium. Solving for real GDP, the interest rate, and the inflation rate simultaneously and combining government spending and government tax revenues into a new variable called the government deficit, one can write the equilibrium real GDP as:

$$
Y=X \beta+e,
$$

where $Y$ is the equilibrium real GDP in Brazil, $\beta$ is a vector of the regression parameters, e is the error term, and $\mathrm{X}$ is a vector containing real money supply (MS), central government deficit (GD), the real BRL/USD exchange rate (EX), the real stock price index (SP), world output (WY), the world interest rate (WI), and the expected inflation rate $(\mathrm{EI})$.

We expect that the impacts of the MS, SP, and WY on real GDP are positive whereas the impacts of other variables on real GDP are unclear. Although government deficit spending is expected to increase aggregate expenditures and real output in the short run, deficit-financed expansionary fiscal policy may have a neutral or an unclear impact on real output in the long-run due to complete crowding-out or the uncertainty about the values of the multiplier and regression parameters (Barro, 1989; Taylor, 2009). The sign of the coefficient for EX is ambiguous as real depreciation of the Brazilian real is expected to result in mixed impacts due to increased exports, increased import prices and domestic inflation, and increased net international capital outflows. A higher world interest rate would lead to a weaker Brazilian real and more net exports but cause increased net international capital outflows, which reduce the supply of capital for economic growth. A higher expected inflation rate would reduce aggregate supply but leads to a lower real interest rate.

In equation (1), the error term is assumed to be independently and identically distributed with the following properties:

$N\left(0, \sigma_{t}^{2}\right)$,

where $\sigma_{t}^{2}$ in the GARCH(m,n) model (Bollersev, 1986) can be expressed as:

$\sigma_{t}^{2}=\phi_{0}+\phi_{1} e_{t-1}^{2}+\ldots+\phi_{m} e_{t-m}^{2}+\alpha_{0}+\alpha_{1} \sigma_{t-1}^{2}+\ldots+\alpha_{n} \sigma_{t-n}^{2}$

\section{EMPIRICAL RESULTS}

The source of the data came from the 2010 issue of IMF's International Financial Statistics. Y is measured in billion reais. MS is represented by real M2 money supply, which is calculated as nominal M2 money supply divided by the consumer price index and multiplied by 100. Real M1 money supply is not considered because it is narrow definition of money and may not be representative of the quantity of money related to economic activities. SP is represented by the nominal share price divided by the consumer price index multiplied by 100 . EX is represented by the nominal exchange rate of the reais per U.S. dollar times the price in the U.S. and divided by the price in Brazil. The government deficit as a percent of nominal GDP is used to measure GD. Using a ratio is more appropriate as the government deficit is likely to rise when more output and income are generated. EI is represented by the average inflation rate of the past four quarters. World industrial production is chosen to measure WY. The U.S. Treasury bill rate is selected to represent WI. Due to seasonal variations, quarterly binary variables - Q1, Q2, and Q3 - are included in the estimated regression. Except for variables with zero or negative values, the logarithmic scale is used. The sample runs from 1996.Q1 to 2009.Q3 and has 55 observations. 
Estimated regression parameters, the variance equation and other related statistics are presented in Table 1. The GARCH(1,1) model is applied in empirical estimation as the coefficients of the past squared error and the past error variance are significant at the $10 \%$ and $1 \%$, respectively. The coefficients of the GARCH model with a higher order are insignificant at the $10 \%$ level. The variable Q2 is dropped out of the regression due to its insignificant coefficient at the $10 \%$ level. In the estimated regression, $97.2 \%$ of the change in real GDP can be explained by the right-hand side variables. All the coefficients are significant at the $1 \%$ or $5 \%$ level.

According to the signs and significance of the estimated parameters, real GDP in Brazil is positively associated with real M2 money supply, the real stock price index, world output, the expected inflation rate and the seasonal binary variable Q3, and it is negatively affected by the government deficit as percent of GDP, real depreciation of the Brazilian real, the U.S. Treasury bill rate, and the seasonal binary variable Q1. Specifically, if real M2 money supply rises by $1 \%$, real GDP will increase by $0.244 \%$; a $1 \%$ real depreciation of the Brazilian real will cause real GDP to decline by $0.078 \%$; if the real stock price index rises by $1 \%$, real GDP will increase by $0.036 \%$; and a $1 \%$ increase in world output will cause real GDP to rise by $0.472 \%$. Hence, in percentage terms, a strong world economy and expansionary monetary policy have more impacts than other variables. The mean absolute percent error (MAPE) of $2.310 \%$ suggests that the forecast error of the regression is relatively low.

Several comments can be made. Monetary easing by increasing real money supply would raise real output. Expansionary fiscal policy by increasing government deficit spending would reduce real GDP. The negative significant coefficient of the real exchange rate suggests that real depreciation of the Brazilian real would hurt real GDP partly because the negative effect outweighs the positive effect. The positive significant coefficient of the real stock price index suggests that real spending in the private sector would increase in response to a higher real stock price. Increased world output would increase Brazil's net exports and raise its real GDP. A higher U.S. Treasury bill rate is expected to reduce the net international capital inflow, raise Brazil's real interest rate, and slow down its economic activities.

To test if the estimated regression may be spurious, we apply the ADF unit root test of the regression residuals. A lag length of zero is selected. The test statistic is estimated to be -4.473 , which is greater than the critical value of -2.608 in absolute values at the $1 \%$ level. Hence, these time series variables have a long-term stable relationship.

Table 1. GARCH Estimation of $\log (\mathbf{Y})$ for Brazil

\begin{tabular}{|c|c|c|}
\hline Variable & Coefficient & z-Statistic \\
\hline Intercept & -0.107 & 0.836 \\
\hline $\begin{array}{l}\log (\mathrm{MS}) \\
\end{array}$ & $0.244 *$ & 6.780 \\
\hline GD & $-0.006^{*}$ & -2.797 \\
\hline $\log (E X)$ & $-0.078^{*}$ & -3.292 \\
\hline $\log (\mathrm{SP})$ & $0.036 * *$ & 2.401 \\
\hline $\log (\mathrm{WY})$ & $0.472^{*}$ & 5.790 \\
\hline $\log (\mathrm{WI})$ & $-0.016^{*}$ & -2.505 \\
\hline EI & $0.014 *$ & 3.812 \\
\hline $\mathrm{Q} 1$ & $-0.041 *$ & -8.453 \\
\hline $\mathrm{Q} 3$ & $0.031^{*}$ & 5.082 \\
\hline \multicolumn{3}{|l|}{ Variance Equation } \\
\hline $\operatorname{RESID}(-1)^{\wedge} 2$ & $-0.196 * * *$ & -1.878 \\
\hline GARCH(-1) & $0.837 *$ & 2.899 \\
\hline Adjusted R-squared & 0.972 & \\
\hline AIC & -4.879 & \\
\hline F-statistic & 155.433 & \\
\hline MAPE & $2.310 \%$ & \\
\hline Sample period & 1996.Q1-2009.Q3 & \\
\hline Sample size & 55 & \\
\hline
\end{tabular}

Notes: Figures in parenthesis are t-statistics. *,** and *** indicate the $1 \%, 5 \%$ and $10 \%$ significance levels, respectively. AIC is Akaike information criterion. MAPE is the mean absolute percent error. 


\section{SUMMARY AND CONCLUSIONS}

This paper has examined the impacts of the aggregate economic and financial conditions on real GDP in Brazil based on an open-economy macroeconomic model. Regression parameters are estimated by the GARCH model. The sample period runs from 1996.Q1 to 2009.Q3. The estimated regression can explain approximately 97.2\% of the behavior of real GDP in Brazil. More real money supply, a lower government deficit as a percent of GDP, real appreciation of the Brazilian real, a higher real stock price, more world output, a lower world interest rate, and a higher expected inflation rate are expected to raise real GDP. Seasonal effects are found in the first and third quarters.

There are several policy implications. Expansionary monetary policy as represented by increased real M2 money supply is effective in increasing real GDP. Like some other countries, it seems that increased budget deficits as a percent of GDP would pose a serious concern for Brazil because of its negative impact on real GDP. Although some scholars advocate real depreciation of a currency to stimulate exports, create job opportunities, and increase income, our empirical results indicate a negative impact of real depreciation of the Brazilian real on real output. This is partly because the central bank of Brazil has adopted an inflation targeting policy since 1999 and is likely to raise the real interest rate to contain higher inflation due to real depreciation. A healthy stock market would be conducive to economic growth. Hence, the authorities may want to take measures to develop and strengthen the stock market and reduce irregularities. Brazil's economy is affected by the world economy and the U.S. interest rate. As output and income in advanced countries gradually rise and as the Fed continues to keep the interest rate at a relatively low level, it will prove beneficial to Brazil's economy.

There may be areas for future research. If the data are available, the ratio of the government debt to GDP may replace the ratio of the government budget deficit to GDP, and the trade-weighted real effective exchange rate (REER) may substitute for the real BRL/USD exchange rate to compare the outcomes. Other macroeconomic models may be considered.

\section{AUTHOR INFORMATION}

Yu Hsing holds a Ph.D. degree from the University of Tennessee and is professor of Economics. His areas of research include macroeconomics, international economics, economic development, transition economics, etc. E-mail: yhsing@ selu.edu.

Susan Zee is an Associate Professor of Supply Chain Management at Southeastern Louisiana University. She teaches management science, operations management, and business statistics. Her research interests include business ethics, quality management, organizational culture, and green movement.

Michael Craig Budden is a Professor of Marketing at Southeastern. His research interests include marketing and financial strategy, retail management, law and business education. E-mail: mbudden@selu.edu. Corresponding author.

Dr. Robert Cope is a Professor of Operations Management and Interim Department Head for Marketing and Supply Chain Management at Southeastern Louisiana University in Hammond, Louisiana. He received a Ph.D. in Business Administration in 1998 from Louisiana State University with a concentration in Information Systems and Decision Sciences. He currently teaches courses in Management Science, Project Management, and Logistics Management and Transportation. His research interests include resource optimization techniques, scheduling, statistical modeling, and the design of information technology. E-mail: Robert.Cope@selu.edu.

\section{REFERENCES}

1. Adrogué, R., Cerisola, M., \& Gelos, G. (2008). Brazil's long-term growth performance: trying to explain the puzzle. Journal of Economic Studies, 37(4), 356-376.

2. Barbosa-Filho, N. H. (2008). Inflation targeting in Brazil: 1999-2006. International Review of Applied Economics, 22(2), 187-200. 
3. Barro, R. J. (1989) The Ricardian approach to budget deficits. Journal of Economic Perspectives, 3(2), $37-$ 54.

4. Bollersev, T. (1986) Generalized autoregressive conditional heteroskedasticity. Journal of Econometics, 31(3), 307-327.

5. $\quad$ Bernanke, B. S. and Blinder, A. S.. (1988), Credit, money, and aggregate demand. American Economic Review, 78(2), 435-439.

6. Canarella, G., \& Pollard, S. K. (2007). A switching ARCH (SWARCH) model of stock market volatility: some evidence from Latin America. International Review of Economics, 54(4), 445-462.

7. Cerisola, M., \& Gelos, G. (2009). What drives inflation expectations in Brazil? An empirical analysis. Applied Economics, 41(10-12), 1215-1227.

8. Diamandis, P. F. (2008). Financial liberalization and changes in the dynamic behaviour of emerging market volatility: evidence from four Latin American equity markets. Research in International Business and Finance, 22(3), 362-377.

9. Ferrari-Filho, F. and Spanakos, A. (2009) Why economic performance has differed between Brazil and China? a comparative analysis of Brazilian and Chinese macroeconomic policy. Revista Venezolana de Análisis de Coyuntura, 15(1), 111-133.

10. Galí, J. (1992), How well does the IS-LM model fit postwar U.S. data? Quarterly Journal of Economics, 107(2), 709-738.

11. Gomes, F. A. R., \& Paz, L. S. (2005). Can real exchange rate devaluation improve the trade balance? The 1990-1998 Brazilian case. Applied Economics Letters, 12(9), 525-528.

12. Gujarati, D. N. \& Porter, D. C. (2010). Essentials of Econometrics. (4th ed.). Boston: McGraw-Hill/Irwin.

13. Guttler, C., Meurer, R., \& Da Silva, S. (2008). Is the Brazilian stock market efficient? Economics Bulletin, 7(1), 1-16.

14. Hsing, Y. (2008). A study of the J-curve for seven selected Latin American countries. Global Economy Journal, 8(4), 1-12.

15. International Monetary Fund (2009), IMF Executive Board concludes Article IV consultation with Brazil. Public Information Notice (PIN) No. 09/92, http://www.imf.org/external/np/sec/pn/2009/pn0992.htm (July 28, 2009)

16. International Monetary Fund (2010) IMF Executive Board concludes Article IV consultation with Brazil. Public Information Notice (PIN) No. 10/111, August 5, 2010. http://www.imf.org/external/np/sec/pn/2010/pn10111.htm

17. Kalyoncu, H., Ozturk, I., Artan, S., \& Kalyoncu, K. (2009). Devaluation and trade balance in Latin American countries. Zbornik Radova Ekonomskog Fakulteta u Rijeci: Casopis za Ekonomsku Teoriju i Praksu/Proceedings of Rijeka School of Economics: Journal of Economics and Business, 27(1), 115-128.

18. Lyons, J. (2010). Brazil's surging currency takes stage in vote --- Next government will face pressure to act amid export-related anxiety; Goldman Dubs the real 'most overvalued. Wall Street Journal. (Eastern edition). New York, N.Y.: Oct 2, A.10.

19. Mankiw, N. G. (1988) Recent developments in macroeconomics: a very quick refresher course. Journal of Money, Credit \& Banking, Part 2, 20(3), 436-449.

20. O'Grady, M. A. (2010) The Fed vs. Brazil's Reformers. Wall Street Journal (Eastern edition). New York, N.Y.: Nov 15, 2010. p. A.15.

21. Rathbone, J. P. (2010). Good fortune helps strengthen Brazil's economy. FT.com. London: June 28.

22. Revier, C. F. (2000) Policy Effectiveness and the Slopes of IS and LM Curves: A Graphical Analysis. Journal of Economic Education, 31(4), 374-381.

23. Romer, D. (2006). Advanced macroeconomics. ( $3^{\text {rd }}$ ed.). Boston: McGraw-Hill/Irwin.

24. Stewart, Alastair, \& Jeffris, Gerald (2010), Brazilian central bank raises key rate. The Wall Street Journal: http://online.wsj.com/article/SB10001424052748704423504575212931696806518.html?KEYWORDS=br azil+economy (April 28, 2010)

25. Stewart, Alastair, Lyons, John, \& Wessel, David (2010), Brazil's fast recovery spurs concern. The Wall Street Journal: http://online.wsj.com/article/SB10001424052748704464704575208532345711208.html?KEYWORDS=br azil+economy (April 27, 2010)

26. Tabak, B. M. (2003). The random walk hypothesis and the behaviour of foreign capital portfolio flows: the Brazilian stock market case. Applied Financial Economics, 13(5), 369-378. 
27. Taylor, J. B. (2009) The lack of an empirical rationale for a revival of discretionary fiscal policy. American Economic Review, 99(2) 550-555.

28. The Economist (2009), Late in, first out: Brazil is the first Latin American country to emerge from recession. http://www.economist.com/displayStory.cfm?story_id=14442343 (September 12, 2009)

29. The Economist (2009), Brazil takes off: now the risk for Latin America's big success story is hubris. http://www.economist.com/displayStory.cfm?story_id=14845197 (November 12, 2009)

30. The Economist (2009), Brazil's recovering economy: juggling technocrats and party hats. http://www.economist.com/displayStory.cfm?story_id=14644374 (October 15, 2009)

31. Worthington, A. C., \& Higgs, H. (2003). An empirical note on the random walk behaviour and market efficiency of Latin American stock markets. Empirical Economics Letters, 2(5), 183-197. 


\section{NOTES}

